\section{Military Technical College Kobry El-Kobbah, Cairo, Egypt}

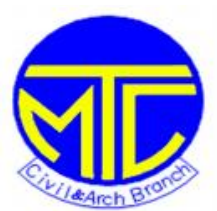

\title{
Effect of Dividing Concrete Target on Perforation Resistance
}

\author{
Mohamed. M. Abdel-Kader* and Ahmed A. Fouda**
}

\begin{abstract}
:
Concrete has been widely used over many years by military and civil engineers in the design and construction of protective structures. One of the loading types that protective structures are designed to withstand, is the localized impact of missiles or projectiles. Parameters that affecting design process are the barrier or target geometry (mainly thickness), and concrete properties. In this paper, the effect of dividing concrete target on perforation resistance was studied through 23 specimens (37 concrete panels) with total different thicknesses $(10,15$ and $60 \mathrm{~cm})$. The thickness of the part of the divided target that faces the impacting missile was also studied. The study showed that dividing concrete target ha d positive effect on perforation resistance provided that the biggest divided mass faces the impact missile.
\end{abstract}

\section{Keywords:}

Concrete; Penetration; Perforation; Impact; Damage; Missile.

\section{Nomenclature}

A the projectile maximum cross section area $\left(\right.$ in $^{2}$ ).

$d \quad$ the projectile diameter (in).

$C$ slenderness ratio factor of projectile [ $C=0.003$ for $(L / d \geq 10) ; 0.002(L / d \leq 10)]$. Where $(L)$ is the projectile length.

$e \quad$ the perforation thickness (in), i.e. the maximum thickness of a target which a missile with a given impact velocity will completely penetrate and have a theoretical exit velocity equal zero.

$f_{c} \quad$ the ultimate compressive strength of concrete $\left(\mathrm{lb} / \mathrm{in}^{2}\right)$.

$N \quad$ the projectile shape factor $(N=0.72$ for flat nosed bodies; 0.84 for blunt nosed bodies; 1.00 for spherical end bullet nose; and 1.14 for very sharp nose).

$s \quad$ the scabbing thickness (in), i.e. the thickness of target required to prevent scabbing of material from rare face of the target for a missile with a given impact velocity.

$S_{i} \quad$ soil penetration factor $\left(S_{i}=5.0\right.$ for medium dense sand).

$V \quad$ the striking velocity of the projectile $(\mathrm{ft} / \mathrm{s})$.

$W \quad$ the projectile total weight (lb).

$x$ the penetration depth (in), i.e. the depth which a missile will penetrate into an infinitely thick target.

$X_{f} \quad$ final penetration value in soil (ft).

* Lecturer, Obour High Institute for Eng. and Tech., Cairo, Egypt. kadermoh@hotmail.com

** Engineering consultant office, Egyptian armed forces, Egypt. Fodaeng@hotmail.com 


\section{Introduction}

Concrete is a common material for protective structures to resist impact and explosive loads. The local effect phenomenon for hard missile impact to concrete target is shown in Fig . 1. In this figure it is clear that if a missile strikes a concrete target with high velocity, pieces of concrete will spall "eject" from the front face of the impacted target forming a crater that is greater than the cross section area of the impacting missile. As the velocity increases, the missile will penetrate the target to depths beyond the depth of the spall crater, forming a cylinder penetration hole with a diameter only slightly greater than the missile diameter. Further increase in velocity produces cracking of the concrete target back face followed by scabbing of concrete [1]. Many formulae were developed to determine the penetration depth $(x)$, the perforation thickness $(e)$ and the scabbing thickness $(s)$ of a concrete target. Some of these formulae were conservative or underestimate penetra tion values. In 1984, Haldar and Hamieh [2] summarized most of the damage -predicting equations commonly used to estimate the local effect of non-deformable missiles on concrete. Haldar and his associates proposed a non-dimensional impact factor $(I)$ which was defined as:

$$
I=\frac{12}{32.2} \frac{N W V^{2}}{d^{2} f_{C}}
$$

The proposed functional relationship between the impact factor and both of the penetration depth $(x)$, the scabbing thickness $(s)$ were summarized as follows:

$$
\begin{array}{ll}
\frac{x}{d}=0.6470+0.0567 I & (4.0 \leq I \leq 21.0) \\
\frac{x}{d}=1.1875+0.0299 I & (21.0 \leq I \leq 455.0) \\
\frac{s}{d}=3.3437+0.0342 I & (21.0 \leq I \leqq 385.0)
\end{array}
$$

According to Haldar and Hamieh [2], the predictability of these equations were found to be superior to the corresponding equations of penetration. As a conservative assumption, scabbing thickness $(s)$ in Haldar formulae was taken as perforation thickness $(e)$.

To predict penetration in soil layers, the Army Corps of En gineers (ACE) presented the following formula [3]:

$$
X_{f}=C S_{i} N(W / A)^{u s}(V-100)
$$

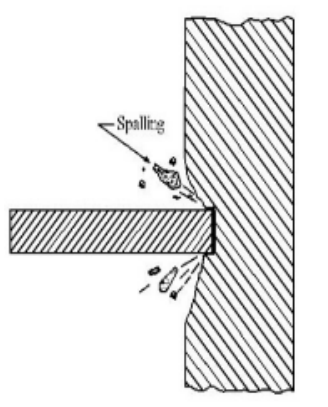

a) Missile Penetration and Spalling

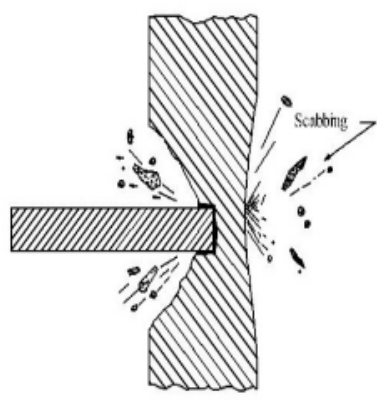

b) Target Scabbing.

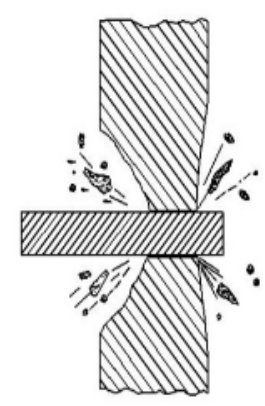

c) Perforation 
Fig. 1. Missile impact phenomena

\section{Experiments}

The impact tests were conducted in the laboratory using a gun that accelerated a blunt-nose projectile of yield strength (1726 MPa), Brinell hardness number (475) and mass (175 g). The projectile was $23 \mathrm{~mm}$ diameter and $64 \mathrm{~mm}$ length. Impact velocities were measured with electro optical velocity measurement device. The tested specimens were concrete panels with dimension of $50 \mathrm{~cm} \times 50 \mathrm{~cm}$ and different thicknesses. The compressive strength of the used concrete was $250 \mathrm{~kg} / \mathrm{cm}^{2}$. Test specimens were mounted on stationary stiff steel frame at distance of 50 meters in front of the gun.

To study the effect of dividing concrete target on penetration resistance, number of 23 specimens (37 concrete panels) with total thickness of 10,15 and $60 \mathrm{~cm}$ were tested. To identify the missile perforation velocity for undivided concrete s pecimens, three specimens were tested for each thickness under different incremental projectile impact velocity until full perforation occurred. The front and back face crater area and depth were measured for each panel under different impact velocities.

\section{$2.110 \mathrm{~cm}$ specimens divided into two $5 \mathrm{~cm}$ panels.}

The $10 \mathrm{~cm}$ specimen was divided into two equal panels of $5 \mathrm{~cm}$ thickness for each. The two 5 $\mathrm{cm}$ panels were tested first with $1 \mathrm{~cm}$ empty space in between as shown in Fig. 2, and second using $1 \mathrm{~cm}$ sand in between as shown in Fig. 3. Table 1 shows the test results for the divided $10 \mathrm{~cm}$ panels compared with that of the undivided panels .

\section{$2.215 \mathrm{~cm}$ specimens divided into 10 and $5 \mathrm{~cm}$ panels.}

To study the variation effect of panel thickness that faces the impacted projectile on penetration resistance, the $15 \mathrm{~cm}$ specimens was divided into two panels of $10 \mathrm{~cm}$ and $5 \mathrm{~cm}$ thickness. The two panels were tested in two positions as follows:

- The $10 \mathrm{~cm}$ panel was in the front facing the impact projectile, and the $5 \mathrm{~cm}$ panel in the back.

- The $5 \mathrm{~cm}$ panel was in the front, and the $10 \mathrm{~cm}$ panel in the back.

The test results of the divided and undivided specimens are shown in Table 2 and Fig. 4.

\section{$2.360 \mathrm{~cm}$ specimens divided into 40 and $20 \mathrm{~cm}$ panels.}

$60 \mathrm{~cm}$ specimen was divided into two panels of $40 \mathrm{~cm}$ thickness as a front panel facing the impact projectile, and $20 \mathrm{~cm}$ as a back panel. The test results of the divided and undivided specimens are shown in Table 3 and Fig. 5.

Table 1. Results of $10 \mathrm{~cm}$ concrete specimens

\begin{tabular}{|c|c|c|c|l|}
\hline \hline Specimen & $\begin{array}{c}\text { Impact } \\
\text { velocity } \\
(\mathrm{m} / \mathrm{s})\end{array}$ & $\begin{array}{c}\text { Front face } \\
\text { crater area } \\
\left(\mathrm{cm}^{2}\right)\end{array}$ & $\begin{array}{c}\text { Back face } \\
\text { crater area } \\
\left(\mathrm{cm}^{2}\right)\end{array}$ & Notes \\
\hline One $10 \mathrm{~cm}$ panel & 275 & 144 & 563 & $\begin{array}{l}\text { - Full perforation. } \\
- \text { Projectile found near the } \\
\text { specimen. }\end{array}$ \\
\hline
\end{tabular}




\begin{tabular}{|c|c|c|c|l|}
\hline $\begin{array}{c}\text { Two } 5 \mathrm{~cm} \text { panels } \\
\text { with } \\
1 \mathrm{~cm} \text { empty space in } \\
\text { between }\end{array}$ & 255 & 54 & 325 & $\begin{array}{l}- \text { Full perforation for both } \\
\text { two panels. }\end{array}$ \\
\hline $\begin{array}{c}\text { Two } 5 \mathrm{~cm} \text { panels } \\
\text { with } \\
1 \mathrm{~cm} \text { sand in } \\
\text { between }\end{array}$ & 285 & 63 & 320 & $\begin{array}{l}\text { - Projectile was captured } \\
\text { by the panels. }\end{array}$ \\
\cline { 2 - 5 } & 295 & 57 & 415 & $\begin{array}{l}\text { - Projectile was captured } \\
\text { by the panels. }\end{array}$ \\
\hline
\end{tabular}

Table 2. Results of $15 \mathrm{~cm}$ concrete specimens

\begin{tabular}{|c|c|c|c|l|}
\hline \hline Sample type & $\begin{array}{c}\text { Impact } \\
\text { velocity } \\
(\mathrm{m} / \mathrm{s})\end{array}$ & $\begin{array}{c}\text { Front face } \\
\text { crater area } \\
\left(\mathrm{cm}^{2}\right)\end{array}$ & $\begin{array}{c}\text { Back face } \\
\text { crater area } \\
\left(\mathrm{cm}^{2}\right)\end{array}$ & \multicolumn{1}{|c|}{ Notes } \\
\hline One $15 \mathrm{~cm}$ panel & 400 & 171 & 222 & - Full perforation. \\
\hline $\begin{array}{c}\text { Two panels of } 5 \mathrm{~cm} \text { as } \\
\text { front panel and } 10 \mathrm{~cm} \\
\text { as back panel }\end{array}$ & 410 & 230 & 720 & $\begin{array}{l}- \text { Full perforation } \\
\text { - Damage for both panels. }\end{array}$ \\
\cline { 2 - 5 } & 425 & 180 & 850 & $\begin{array}{l}\text { - Full perforation. } \\
\text { - Severe damaged in } \\
\text { the 10 cm panel. }\end{array}$ \\
$\begin{array}{c}\text { Two panels of } 10 \mathrm{~cm} \\
\text { as front panel and } 5 \mathrm{~cm} \\
\text { as back panel }\end{array}$ & 425 & 220 & $\begin{array}{l}\text { - Projectile was captured } \\
\text { by the front panel. } \\
\text { - The back panel totally } \\
\text { cracked. } \\
\text { - Small dent was found in } \\
\text { the back panel front face. }\end{array}$ \\
\hline \hline
\end{tabular}

Table 3. Results of $60 \mathrm{~cm}$ specimens.

\begin{tabular}{|c|c|l|}
\hline \hline Sample type & $\begin{array}{c}\text { Impact } \\
\text { velocity } \\
(\mathrm{m} / \mathrm{s})\end{array}$ & Notes \\
\hline One panel $(60 \mathrm{~cm})$ & 980 & - The panel was totally destroyed. \\
\hline
\end{tabular}




\begin{tabular}{|c|c|c|}
\hline \multirow{2}{*}{$\begin{array}{c}\text { Two panels } \\
(40 \text { and } 20 \mathrm{~cm})\end{array}$} & $\begin{array}{l}\text { - The } 40 \mathrm{~cm} \text { front panel was totally destroyed } \\
\text { with slight effect on the back panel. } \\
\text { - No cracks was found on front and back face } \\
\text { of the back panel. only a dent of } 1 \mathrm{~cm} \\
\text { diameter and } 0.5 \mathrm{~cm} \text { depth was found at the } \\
\text { front face of the back panel. }\end{array}$ \\
\hline \hline
\end{tabular}

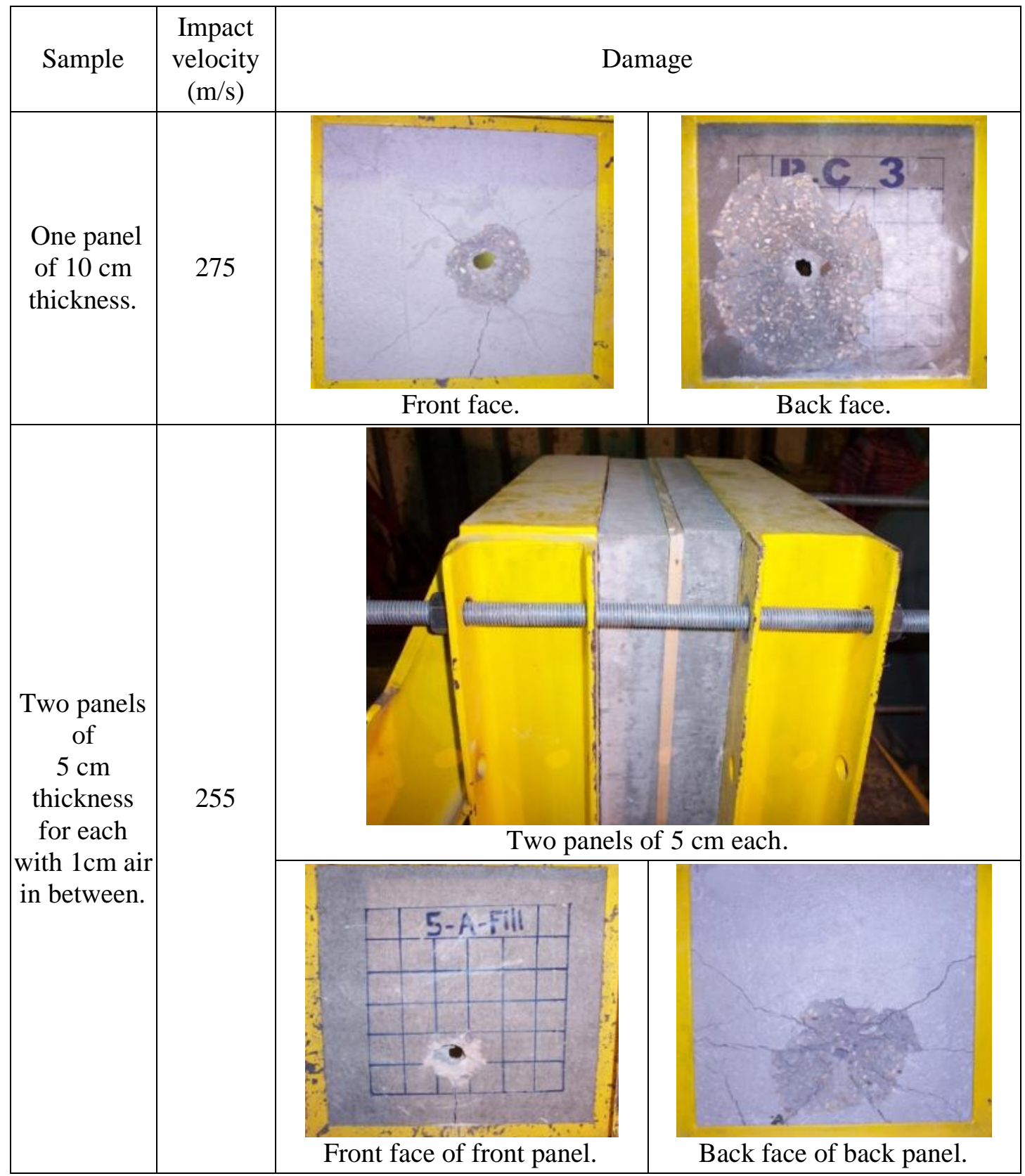




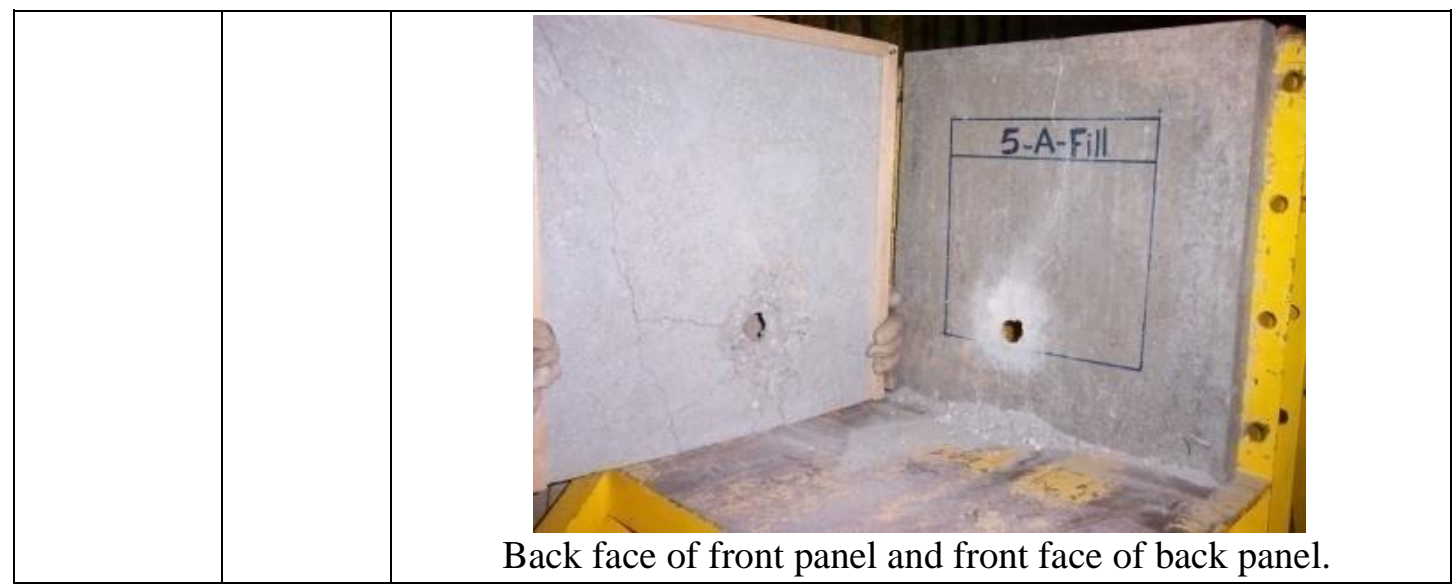

Fig. 2. $10 \mathrm{~cm}$ concrete specimens with $1 \mathrm{~cm}$ air in between.

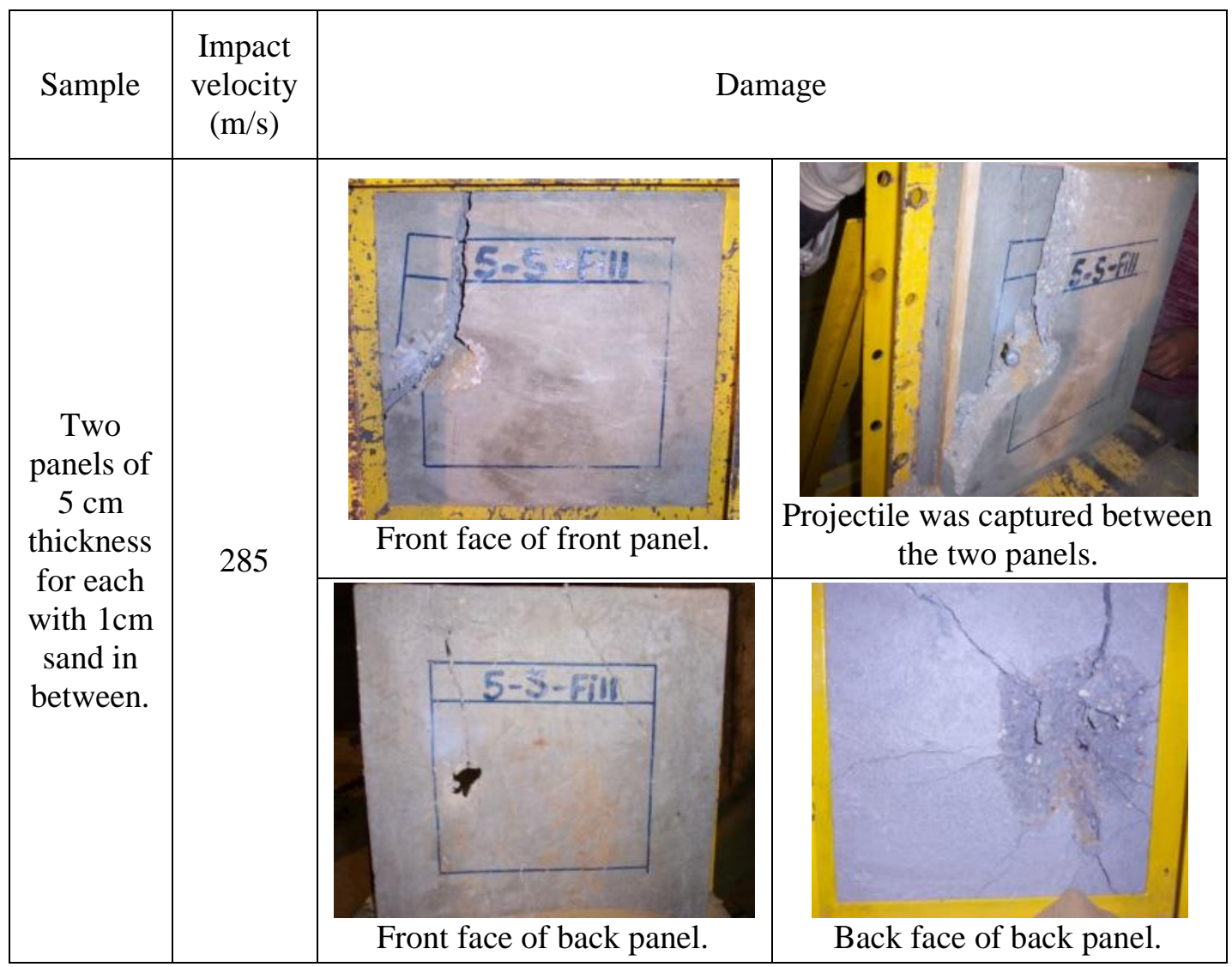




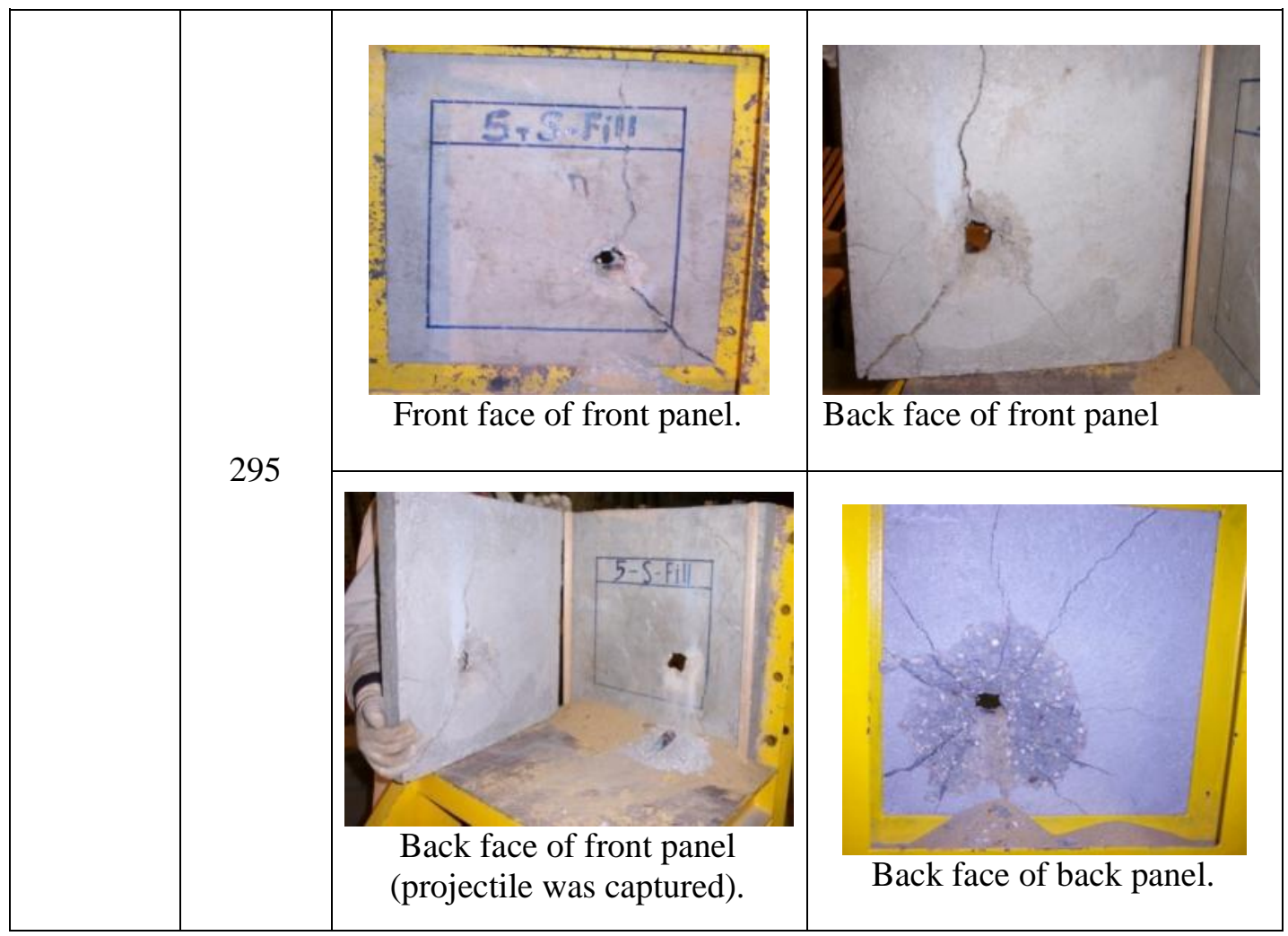

Fig. 3. $10 \mathrm{~cm}$ concrete specimens with $1 \mathrm{~cm}$ sand in between.

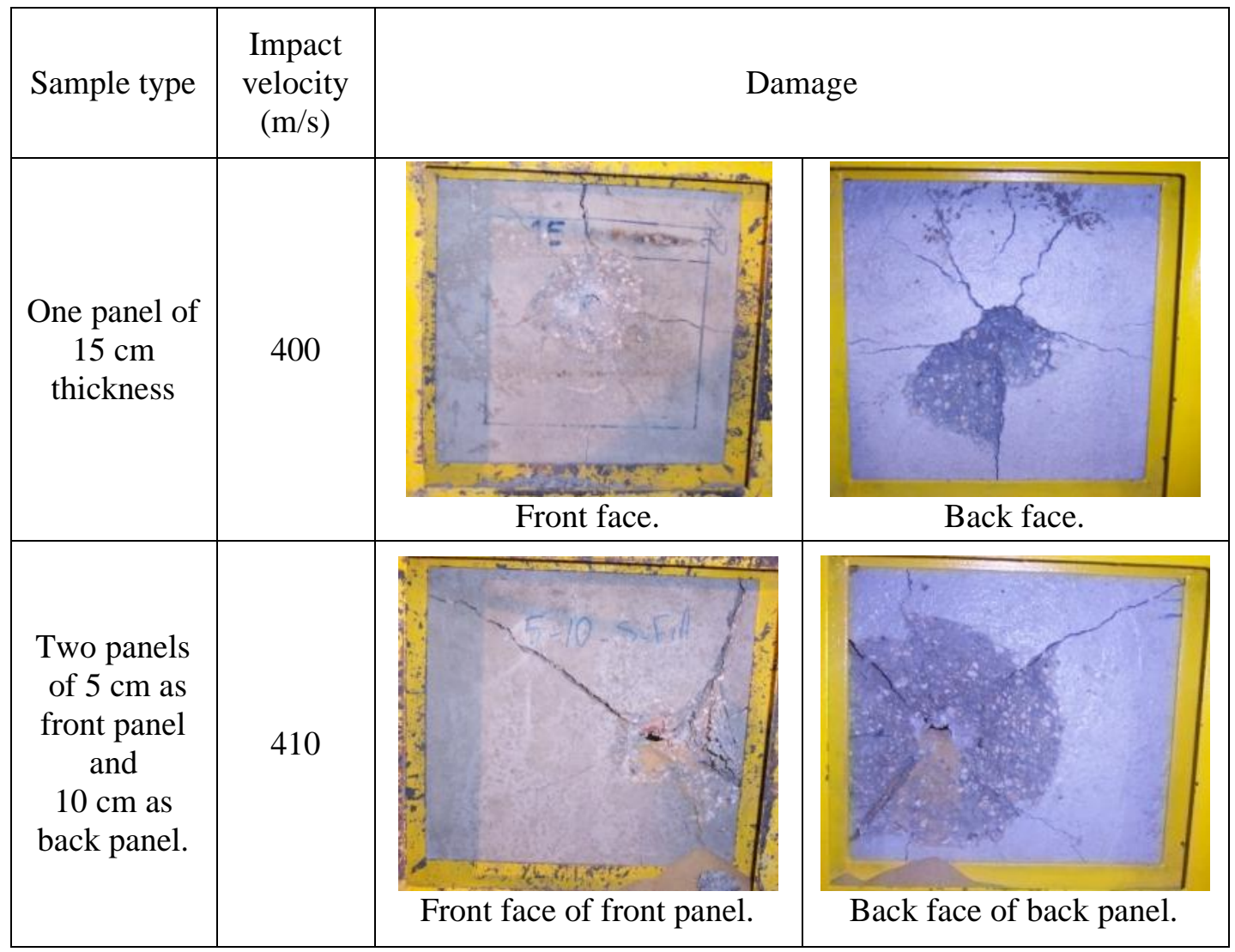




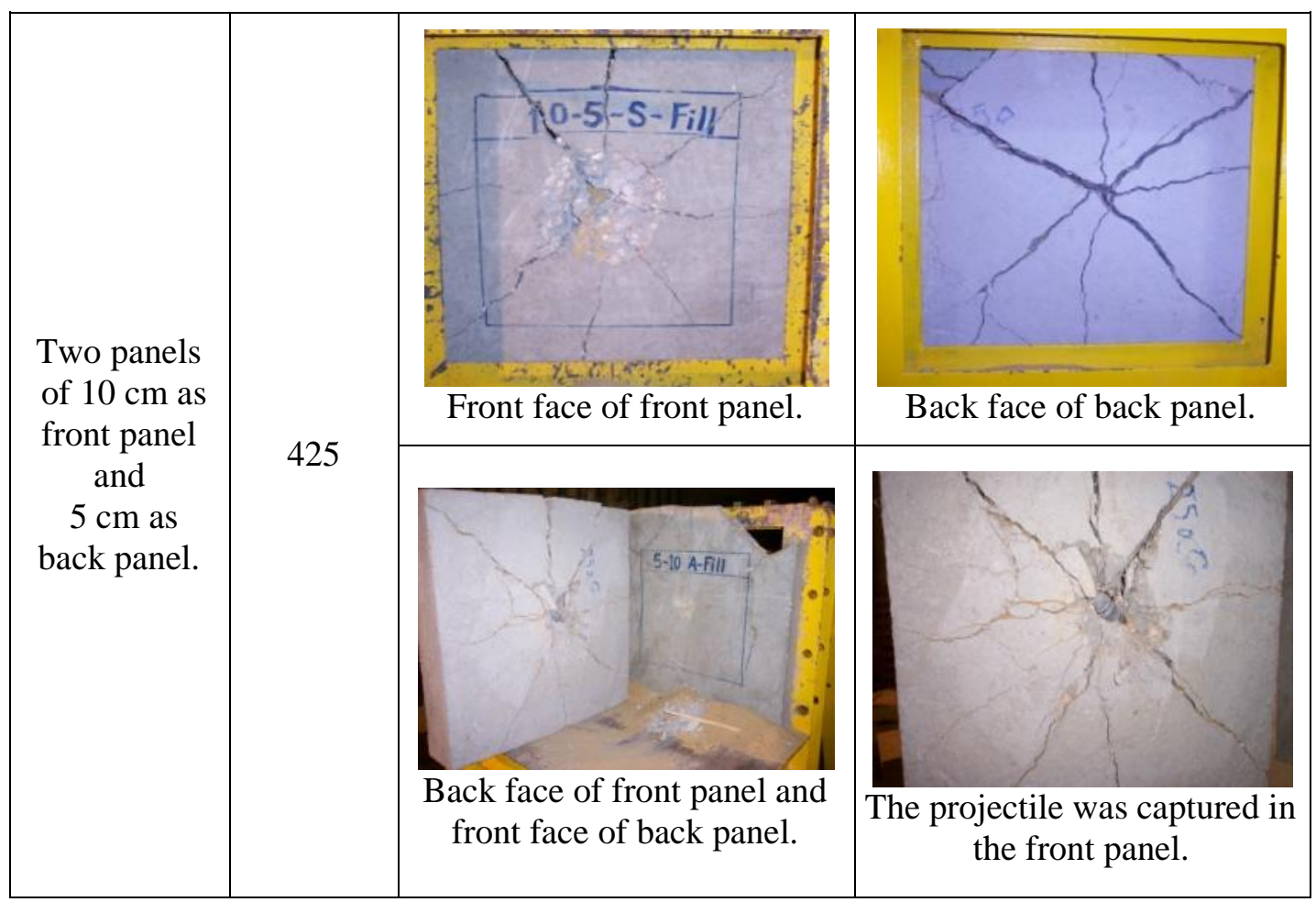

Fig. 4. $15 \mathrm{~cm}$ concrete specimen with $1 \mathrm{~cm}$ sand in between.

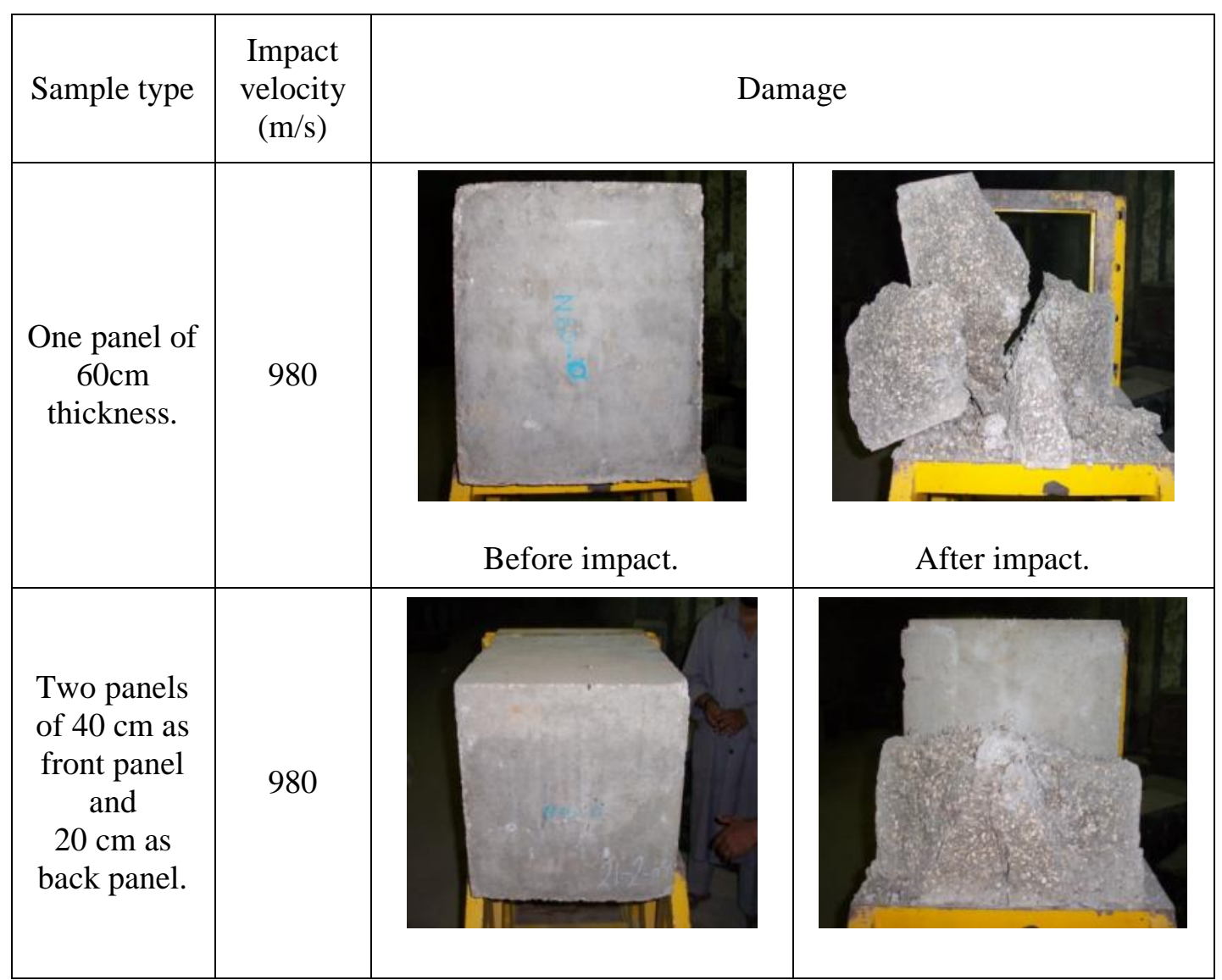




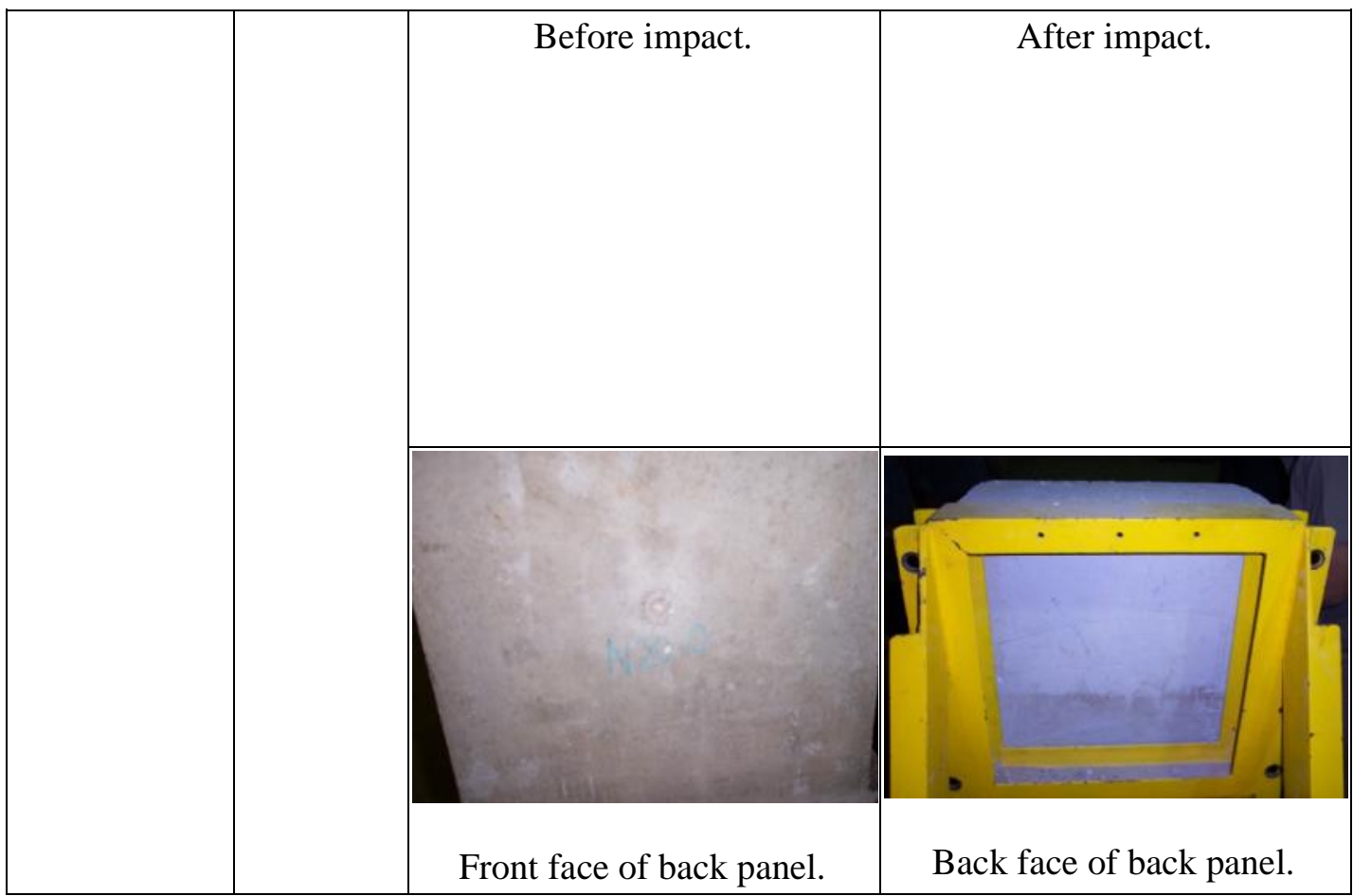

Fig. 5. $60 \mathrm{~cm}$ thickness concrete specimens.

\section{Discussion}

\section{$3.1 \quad 10 \mathrm{~cm}$ specimens $(5 \mathrm{~cm}+5 \mathrm{~cm})$.}

As shown in Table 1 and Fig. 2, the dividing process "without using any filler between the panels" decreased penetration resistance. This is clear as the velocity that caused full perforation of the divided specimen was $255 \mathrm{~m} / \mathrm{s}$ while the velocity that caused full perforation of the undivided $10 \mathrm{~cm}$ specimen was $275 \mathrm{~m} / \mathrm{s}$. The front panel of $5 \mathrm{~cm}$ thickness is considered thin, as the ratio of the panel thickness $(t)$ to the projectile diameter $(d)$ is less than $5.0[1],(t / d=5.0 / 2.3=2.18<5$. For thin targets subjected to impact velocity higher than its penetration resistance, it was found that the penetration depth increased rapidly accompanied by wider scabbing area and larger fragmen ts volume and velocity [1]. According to the this reason, the portion of impact energy absorbed by the front panel was too small to stop the projectile; and consequently the residual impact energy "after perforating the front panel" caused full perforation to the back $5 \mathrm{~cm}$ panel. The total impact energy in this case was lower than that required for perforating the undivided specimen. As shown in Table 1 and Fig. 3, using $1 \mathrm{~cm}$ of sand filler between the two panels improved perforation resistance. Although projectile impact velocity of $295 \mathrm{~m} / \mathrm{s}$ caused damage for both panels, the projectile was captured in between them. In fact, $1 \mathrm{~cm}$ of sand filler did not significantly increase the concrete panel resistance from the thickness increase point of view due to the following reason:

Using equation (4) for projectile impact velocity of $275 \mathrm{~m} / \mathrm{s}$, it was found that the theoretical perforation thickness equal $11.2 \mathrm{~cm}$. According to equation (5), the final penetration depth in dense sand equal $117 \mathrm{~cm}$. This shows that, the penetration resistance in sand is about $10 \%$ of the concrete penetration resistance. This means that using $1 \mathrm{~cm}$ sand filler is equivalent (in resisting penetration) to about $1 \mathrm{~mm}$ of concrete, which is insignificant increase in target 
Proceedings of the $\mathbf{9}^{\text {th }}$ ICCAE-9 Conference, 29-31 May, 2012

thickness. The benefit of sand filler in this case is to prevent concrete scabbing at back face of the front panel and to preserve the continuity of the target.

\section{$3.215 \mathrm{~cm}$ specimens $(10 \mathrm{~cm}+5 \mathrm{~cm})$.}

As it can be seen from Table 2 and Fig. 4, using the $5 \mathrm{~cm}$ panel in front and $10 \mathrm{~cm}$ panel in the back; did not affect the specimen perforation resistance. In this case the two panels were totally perforated at approximately the same perforation velocity required for the undivided panel $(410 \mathrm{~m} / \mathrm{s})$. In addition, the damage level represented by the front and back face crater area was found greater than that for undivided panel. This could refer "as explained before" to the fact that the absorbed energy by the front thin panel of $5 \mathrm{~cm}$ thickness was not significant enough and the residual energy cause d full perforation of the back $10 \mathrm{~cm}$ panel.

When the $10 \mathrm{~cm}$ panel faced the impacting projectile and the $5 \mathrm{~cm}$ panel was in the back; the target resisted perforation up to projectile velocity $425 \mathrm{~m} / \mathrm{s}$. The projectile was captured by the front panel, while the back $5 \mathrm{~cm}$ panel was totally cracked. Small dent was found in the back panel front face. This behavior indicates that using front panel with higher thickness to projectile diameter ratio, improved perforation resistance; as most of the impact energy is absorbed by the front panel. The panel thickness $(t)$ to projectile diameter $(d)$ herein was $(t / d=10 / 2.3=4.34)$.

\section{$3.360 \mathrm{~cm}$ specimens $(40 \mathrm{~cm}$ front $+20 \mathrm{~cm}$ back $)$.}

To have more investigation about the effect of front panel thickness to projectile diameter on penetration resistance, $60 \mathrm{~cm}$ thickness specimen was used. The specimen was tested first as undivided sample, and second the specimen was divided into two panels ; $40 \mathrm{~cm}$ thickness as a front panel and $20 \mathrm{~cm}$ panel as a back one. In this case, the front panel thickness to projectile diameter was $(t / d=40 / 2.3=17.4)$. As shown in Table 3 and Fig. 5, the undivided $60 \mathrm{~cm}$ panel was totally destroyed at impact velocity of $980 \mathrm{~m} / \mathrm{s}$. When the divided specimen was subjected to the same impact velocity, the $40 \mathrm{~cm}$ front panel was totally des troyed while slight effect was found on the back panel. Only a dent of $1 \mathrm{~cm}$ diameter and $0.5 \mathrm{~cm}$ depth was found at the front face of the back panel, while no cracks were observed in either back panel faces.

From the analysis, it is noticeable that increas ing the ratio of front panel thickness to projectile diameter $(t / d)$ increased the perforation resistance. More study is needed in this area to identify the optimum $(t / d)$ ratio of front and back panel to improve perforation resistance. In this study, a ratio of $(t / d)$ for front panel not less than 5 was recommended.

\section{Conclusions}

Regarding the behavior of concrete panels subjected to impact loads of hard projectile, the following conclusions were obtained by the present study:

1. Dividing concrete target could increase its perforation resistance .

2. A positive effect on perforation resistance was obtained by dividing concrete targets with setting the panel of bigger thickness in front of the impacting missile. The recommended front panel thickness $(t)$ to projectile diameter $(d)$ in this study was $(t / d \geq 5.0)$.

3. For double-layer concrete wall target, putting sand filler in between layers improve s its perforation resistance.

\section{References}

[1] KENNEDY R.P, "A Review of Procedures for the Ana lysis and Design of Concrete Structures to Resist Missile Impact Effects", Nuclear Engineering and design, Vol.37, 1976, pp. 183-203. 
[2] Haldar A. and Hamieh H.A, "Local Effect of Solid Missile on Concrete", Journal of Structural Engineering, Vol. 110, No. 5, May, 1984, pp. 948-960.

[3] Technical Manual No. 5-855-1, "Fundamental of Protective Design for Conventional Weapons", Headquarters, Department of the Army, Washington, DC, 1986.

[4] Li Q.M, Reid S.R, and Ahmad A.M, "Critical Impact Energies for Scabbing and Perforation of Concrete Target", Nuclear Engineering and design, Vol. 236, 2006, pp. 1140-1148.

[5] Dancygier A.N, "Rear Face Damage of Normal and High -Strength Concrete Elements Caused by Hard Projectile Impact", ACI Structural Journal, Vol. 95. No. 3, May-June 1998, pp. 291-304.

[6] Sliter G.E, "Assessment of Empirical Concrete Impact Formulas", ASCE, Vol. 106, No ST5, May, 1980, pp. 1023-1044.

[7] Mohamed M.E, Eltehawy E.M, and Kamal I.M, "Experimental Analysis of Reinforced Concrete Panels Resistance", Proceedings of the 13th International Conference on Aerospace Sciences and Aviation Technology, ASAT-13," May, 2009, pp. 123-134.

[8] Degen P.P, "Perforation of Reinforced Concrete Slabs by Rigid Missiles", ASCE, Vol. 106, No ST7, July, 1980, pp. 1623-1642.

[9] Haldar A., Hatami M., and Miller F.J, "Concrete structure: Penetration Depth Estimation", Journal of Structural Engineering, Vol. 109, No. 1, January, 1983, pp. 245-250.

[10] Kar A.K, "Local Effect of Tornado-Generated Missiles", ASCE, Vol. 104, No ST5, May, 1978, pp. 809-816.

[11] Dancygier A.N, Yankelevsky D.Z, and Jaegermann C., "Response of High Performance Concrete Plates to Impact of Non-Deforming Projectiles" Int. J. Impact Eng., Vol. 34, (2007), pp.,1768-1779. 